\title{
COMMENTS
}

\section{Emergency Mayoral Power: An Exercise in Charter Interpretation}

In August 1975, San Francisco experienced its first major strike by pohice and fire officers. The walkout occurred after the Board of Supervisors, vested by the Charter of the City and County of San Francisco with the power to set the wages of public safety officers, ${ }^{1}$ passed a salary ordinance granting such personnel a 6.5 percent pay increase, less than half that demanded by the police and fire officers' bargaining representatives. ${ }^{2}$ In an attempt to break the impasse, the parties agreed to mediation by San Francisco Mayor Joseph Alioto. Subsequent talks produced a settlement proposal that, as presented to the Board, called for a 6.5 percent wage increase for the single day of July 1,1975 (for the purpose of retirement protection), no increase for the period July 2, 1975 to October 14, 1975, and a 13.05 percent increase from October 15, 1975 to the end of the fiscal year. ${ }^{3}$ The Board of Supervisors, however, refused to accept the compromise. The Mayor responded to the Board's rejection of the proposal by declaring a "public emergency" under the San Francisco Charter. Pursuant to the declaration, Mayor Alioto attempted to "suspend" the normal wage-setting provisions of the charter in order to implement the compromise package. $^{4}$

1. Charter of the City and County of San Francisco, res. ch. 273, $\$ 8.405,1971$ Cal. Stats. 4756. The citations to municipal charters throughout the text are keyed to the official Statutes of California because copies of the charters themselves are not generally available in law libraries. The charters are referred to in the text by the dates when they became effective, not the dates when they were passed by the voters of the municipality or approved by the state legislature. Thus, the charter approved by the voters of San Francisco in 1898, ratified by the state legislature in 1899 , but effective in 1900, is referred to as the 1900 charter. Similarly, the charter passed by the voters of San Francisco and ratified by the legislature in 1931, but effective in 1932, is referred to as the 1932 charter.

2. S.F. Examiner, Aug. 18, 1975, at 1, col. 1.

3. See Proposed Teutative Settlement, Aug. 21, 1975, presented to the Board of Supervisors by Mayor Joseph Alioto, filed with Verreos v. City \& County of San Francisco, Civil No. 694-432 (Super. Ct. San Francisco, Oct. 27, 1975), on file at the California Law Review.

4. See Proclanation by Mayor Joseph L. Alioto, Aug. 21, 1975, on file at the Office of the Mayor, San Francisco, California, and at the California Law Review. 
The Board of Supervisors retaliated by placing four charter amendinents on the November ballot that would, if passed, limit San Francisco police and fire salaries to the average level of such salaries in California cities with populations of over 350,000 , impose the controversial 14-hour work schedule in the fire services, provide for automatic disinissal of strikers in the future, and curtail the Mayor's emergency powers under the charter by requiring the concurrence of a majority of the Board of Supervisors or a majority of those meinbers inmediately available both as to the need to declare an energency and as to the action proposed to be taken by the Mayor. Police and fire labor organizations sued the City and County of San Francisco, ${ }^{5}$ alleging that the Board's submission of the charter amendments to the electorate without consulting labor representatives violated the "ineet and confer" requirements of the Meyer-Milias-Brown Act. ${ }^{8}$ The charter amendinents reinained on the ballot, however, and were overwhelmingly approved by the voters. ${ }^{7}$

Prior to the November election, a taxpayer filed suit in San Francisco County Superior Court challenging the legality of the Mayor's emergency declaration and strike settlement. The Board of Supervisors, named as a party defendant in the complaint, intervened as a plaintiff against the City and County of San Francisco. In Verreos $v$. City \& County of San Francisco, ${ }^{8}$ the superior court upheld the Mayor's emergency declaration and settlement against the taxpayer's challenge, and the Californa Court of Appeal for the First District affirmed the judgment.

This Comment considers the legality of Mayor Alioto's use of executive emergency powers under the charter. It explores the historical and functional relationships among the municipal legislature, the municipal executive, and state courts, and their relative competence to deal with specific aspects of emergency decisionmaking at the local level. The threshold question is whether the Mayor's declaration of public emergency was "vahid." Underlying this question is an issue of power: which governmental body should have primary responsibility for determining the existence of a public emergency? Resolution of the issue does not call for a techmical discussion of whether a given fact situation approaches an external standard, but requires analysis of the kinds of considerations required to determine whether an einergency

5. San Francisco Fire Fighters Local 798 v. City \& County of San Francisco, Civil No. 700-977 (Super. Ct. San Francisco, Mar. 30, 1976).

6. Cal. Gov'T CODE $\$ 3500-3510$ (West Supp. 1976). See note 36 infra.

7. For a description of the charter amendments and voting statistics of the November 1975 election, see Cebulski, Two Case Studies-Facts and Issues, 27 CAL. PUB. EMPloyee Rels. 19, 23 (Dec. 1975) [hereinafter cited as Two Case Studies].

8. 63 Cal. App. 3d 86, 133 Cal. Rptr. 649 (1st Dist. 1976). 
exists and which governmental body, on balance, is likely to do the best job in translating these considerations into coherent policy. The second question is whether the Mayor's subsequent action-his attempt to impose a settlement-exceeded the scope of his authority under the charter, assuming that a public emergency existed. In connection with this question, the issue of which governmental body should have the power to decide the scope of the Mayor's authority is discussed. Finally, assuming that the state judiciary has the power to overrule determinations of one or both of these questions by the political branches of local governunent, the Comment considers the propriety of a judicial remedy in the context of the San Francisco police and fire strike settlement.

\section{FACTUAL BACKGROUND}

\section{A. The Strike}

For more than 20 years, the City and County of San Francisco paid police and fire officers the equivalent of the highest salaries paid for public safety officers in any comparable city in California. ${ }^{0}$ The San Francisco Charter did not mandate this salary level, but required the San Francisco Civil Service Commission to certify to the Board of Supervisors the prevailimg wages in major California cities. The charter vested power in the Board to fix rates of compensation not to exceed the highest going rate in the Commission survey. ${ }^{10}$ Successful lobbying by police and fire organizations in a city in which labor groups traditionally have been influential, ${ }^{11}$ however, had resulted in the Board setting salaries at the inaximum rate certified by the Civil Service Commission.

In 1975, the Board of Supervisors, believing that San Francisco faced a financial crisis, reevaluated the Board's public safety salary policy. ${ }^{12}$ Although the Civil Service Commission's August survey indi-

9. Two Case Studies, supra note 7, at 19. Custom concerning the payment of compensation by a municipality canuot supersede charter provisions. See 4 E. MCQuiLLiN, MUNiCipal CoRporations $\$ 12.175 \mathrm{~b}$ (3d ed. 1968).

10. Charter of the City and County of San Francisco, res. ch. 273, $\$ 8.405,1971$ Cal. Stats. 4756.

11. See F. Wirt, Power in the City: Decisionmaking in San Francisco 3738 (1974) (noting the rise of Harry Bridges and the increasing power of construction workers, craft workers, printers, and longshoremen); L. PETERSON, THE DAY OF THE MugwUMP 307 (1961) (crediting the political clout of labor to the San Francisco Charter provisions protecting the salaries of public employees); $H$. ZiNK, GovernmENT of THE Crties of the UNITED States 248 (1939) (noting the ability of San Francisco labor to elect the Mayor and several members of the Board of Supervisors at the beginning of the 20th century).

12. Diane Feinstein, President of the Board of Supervisors, stated: "The City's financial situation is so critical we cannot give a $13.05 \%$ increase." S.F. Examiner, Aug. 20, 1975, at 39, col. 1. Supervisor John Molinari, Chairman of the Board's Leg- 
cated that a 13.05 percent salary increase for San Francisco public safety officers would be necessary to match salaries paid by the City of Los Angeles, the Board of Supervisors' Legislative and Personnel Committee, in contrast with previous years, presented the survey results to the full Board without recommendation. ${ }^{13}$ Sensing that the Board was about to depart from tradition by fixing police and fire salaries below the maximum rates allowed by the charter, the San Francisco Police Officers Association and Local 798 of the International Association of Firefighters threatened to strike if the Board refused to approve the 13.05 percent raise. ${ }^{14}$ Nevertheless, on August 18 the full Board passed without dissent a salary ordmance providing public safety officers with a 6.5 percent increase, roughly the same average increase approved for other city workers. ${ }^{15}$

The police and fire associations carried out their strike threat. The police officers' walkout began immediately after the Board's action. According to the Police Officers Association and the news media, 90 percent of the 1800 -member force honored the strike. ${ }^{16}$ The police department patrolled the city with 45 officers, mostly management persormel, and 20 cars, compared to the normal complement of 300 officers and 100 cars. ${ }^{17}$ Although the City and County of San Francisco obtained a temporary restraining order agamst the police strike on August 19, strikers did not observe it. ${ }^{18}$ Firefighters joined the police officers by walking out on August 20 after receiving strike sanction froin the San Francisco Labor Council. As with the police, roughly 90 percent of rank-and-file firefighters participated in the strike as picket lines appeared at many of the city's 44 fire stations. ${ }^{19}$

islative and Personnel Committee, defended the Board's position by citing the "currently extremely stringent fiscal and budgetary restraints on city and state governments," and added that the Board was prepared to grant raises only "within the capacity of the City to fund." S.F. Examiner, Aug. 19, 1975, at 20, col. 2. For a more optimistic picture of San Francisco's financial posture, see Kneeland, San Francisco Remains Solvent, N.Y. Times, Aug. 24, 1975, at 1, col. 6.

13. S.F. Examiner, Aug. 18, 1975, at 14, col. 6.

14. Two Case Studies, supra note 7 , at 20.

15. S.F. Examiner, Aug. 18, 1975, at 1, col. 1. Supervisor Al Nelder, a former Police Chief of the City and County of San Francisco, abstained.

16. Two Case Studies, supra note 5, at 20; S.F. Chronicle, Aug. 19, 1975, at 1, col. 6; N.Y. Times, Aug. 19, 1975, at 20, col. 3.

17. S.F. Chronicle, Aug. 20, 1975, at 1, col. 2.

18. City \& County of San Francisco v. Police Officers Ass'n, Civil No. 694-232 (Super. Ct. San Francisco, Sept. 8, 1975). The City and County was unable to serve process on Police Officers Association President Gerald Crowley, who surrounded himself with bodyguards. Crowley and the Police Officers Association were found in contempt of the temporary restraining order despite the lack of actual service, and fined $\$ 1,000$ each.

19. Two Case Studies, supra note 7, at 19; N.Y. Times, Aug. 21, 1975, at 1, col. 8. 
Of 49 engine companies normally available, 11 were in service; of 18 trucks, only 3 were operational. ${ }^{20}$

The effect of the lack of police protection was difficult to measure. Police management claimed that the walkout was having a "major impact on law enforcement capabilities," apparently were answered. ${ }^{22}$ Arrests fell from a level of 30 to 40 bookings in a normal 8-hour period to near zero. ${ }^{23}$ Increased juvenile vandalism in the Mission District and robberies in the Chinatown area suggested that the strike may have had an adverse affect on crime deterrence. ${ }^{24}$ Although commentators later declared that "no major crime wave" occurred, ${ }^{25}$ a police official told the San Francisco Chronicle on the third day of the strike that "We're in far worse shape than we can imagine. The trouble is, you can't tell how bad it is, because no reports are being taken . . . ."26

20. S.F. Chronicle, Aug. 21, 1975, at 1, col. 6 .

21. N.Y. Times, Aug. 19, 1975, at 20, col. 3.

22. N.Y. Times, Aug. 21, 1975, at 28, col. 5.

23. S.F. Chronicle, Aug. 19, 1975, at 1, col. 5.

24. See N.Y. Times, Aug. 21, 1975, at 28, col. 6. Shop windows were smashed and looting occurred in the Mission District; four restaurants in Chinatown were robbed while patrons dined. Nonstriking police later arrested four suspects.

25. Two Case Studies, supra note 7, at 21.

26. S.F. Chronicle, Aug. 21, 1975, at 2, col. 3. The San Francisco Examiner and the San Francisco Chronicle reported that police pickets were involved in violent incidents. On the first evening of the walkout, striking officers arrested three persons for allegedly firing shots at picketers outside the Ingleside District station. A photograph of police strikers firing at street lights in order to gain a better view of the snipers appeared on the front page of the Examiner, along with a report that two nearly empty bottles of whiskey were located on a card table used by picketers just outside the station. S.F. Examiner, Aug. 19, 1975, at 1, col. 5. Mayor Alioto rebutted charges of excessive drinking by noting that the consumption of liquor by striking officers was "proportionately not greater than drinking among supervisors, the mayor, or most other San Franciscans." S.F. Chronicle, Aug. 23, 1975, at 12, col. 3. Police also arrested an angry motorist for allegedly attempting to run down picketing officers who reportedly fired several shots in making the arrest. S.F. Chronicle, Aug. 19, 1975, at 1, col. 6. Such incidents prompted a local newspaper to declare that the atmosphere at one district police station had "the aura of a combat zone." S.F. Examiner, Aug. 19, 1975, at 1 , col. 5.

Fearing that tragedy might result as tensions grew, the American Civil Libertics Union obtained a restraining order prohibiting police officers from carrying their service revolvers while on picket duty. Fishlow v. Scott, Civil No. 694-284 (Super. Ct. San Francisco, Aug. 20, 1975) (order granting temporary restraining order). This order, however, like the temporary order restraining the strike itself, was not enforced. Two Case Studies, supra note 7, at 20.

Vandalism occurred that secmed to be the acts of strikers. Tires of nonstrikers' personal cars were shredded. S.F. Chronicle, Aug. 21, 1975, at 2, col. 1. The keys to 150 to 200 vehicles in the police auto pool disappeared. S.F. Examiner, Aug. 20, 1975, at 24, col. 3. A bomb exploded in the early morning hours of August 20, at the Mayor's home, accompanied by a sign implanted on the Mayor's lawn bearing the message: "don't threaten us." S.F. Chronicle, Aug. 20, 1975, at 1, col. 6. Although no criminal prosecutions resulted from these acts and authorities apparently have been 
No major fires tested the city's firefighting capacity during the strike, but a threefold increase in false alarms on the first night of the strike compounded the problein presented by the labor shortage. Fire officials handled the difficulty by sending battalion chiefs in autos to respond to alarms before dispatching heavier equipinent. ${ }^{27}$ Firefighters atteinpted to close the San Francisco International Airport by picketing and withdrawing their services, but Federal Aviation Agency and airline officials concluded that supervisory personnel were providing adequate service and operations were not interrupted. ${ }^{28}$ Traffic controllers notified incoming flights of the situation, however, in case the pilots desired to land elsewhere. ${ }^{29}$

\section{B. The Settlement}

In an attempt to break the impasse, the Board of Supervisors and the public safety labor organizations agreed to submit to inediation by Mayor Joseph Alioto. The Board of Supervisors (six unembers of which were facing reelection contests in November) was in an uncompromising mood, however, and when the Mayor was unable to achieve a prompt settlement on terms favorable to the Board, the Supervisors passed an ordinance declaring a state of einergency pursuant to section 8630 of the California Governinent Code and requested the Governor to dispatch 200 California Highway Patrol officers to protect the city. ${ }^{30}$ Mayor Alioto vetoed this ordinance, declaring that it "would escalate the possibility of civil disorder into a dangerous probability."

On August 21, the Mayor presented the Board with a compromise that was acceptable to police and fire labor leaders. The proposal's main feature was a 13.05 percent wage hike, effective October 15, $1975 .^{32}$ According to the Mayor, the proposed settlement would cost San Francisco $\$ 2,651,306$ more than the Board's highest offer but $\$ 4,000,000$ less than that originally demanded by the police and fire orgamizations. $^{33}$ The Board, with little debate, unanimously rejected

unable to identify the perpetrators, reports of such vandalism and sabotage contributed to the atmosphere of tension in San Francisco.

27. S.F. Examiner, Aug. 21, 1975, at 1, col. 4.

28. Id. col. 6 .

29. N.Y. Times, Aug. 21, 1975 at 28, col. 4.

30. City and County of San Francisco, Cal., Proposed Ordinance 398-75 (Aug. 20, 1975), vetoed by Mayor Alioto (Aug. 21, 1975). Once a local governing body proclaims a local emergency pursuant to section 8630 of the California Government Code, political subdivisions and state agencies may provide mutual aid to assist the local government in meeting the emergency. See CAL. Gov'T CODE $\$$ 8631-8632 (West Supp. 1976).

31. S.F. Chronicle, Aug. 22, 1975, at 1, col. 5.

32. See Proposed Tentative Settlement, supra note 3.

33. $I d$. 
the proposal. The Mayor, anticipating the Board's opposition, moved swiftly to implement his solution to the labor problems. On the same day that the Board rejected his proposal, he proclaimed a "public emergency" pursuant to section 3.100 of the Charter of the city and County of San Francisco, which at that time vested power in the Mayor to "do whatever . . . he may deem necessary" to meet an emergency threatening the lives, property, or welfare of the citizens of San Francisco. ${ }^{34}$ Interpreting section 3.100 broadly, the Mayor "suspended" the sections of the charter that vested wage-setting authority in the Board of Supervisors and proclaimed his mediated settlement accepted by the City and County of San Francisco. ${ }^{35}$

II

The Validity of the Mayor's Emergency Declaration

\section{A. The Meaning of "Public Emergency" in Section 3.100}

Before the voters expressed their disapproval of the Mayor's actions by amending the charter provision, the last paragraph of section 3.100, referred to hereinafter as the "unamended" emergency provision, stated:

In case of public emergency involving or threatening the lives, property or welfare of the citizens, or the property of the city and county, the mayor shall have the power, and it shall be his duty, to summon, organize, and direct the forces of any department in the city and county in any needed service; to sunmon, marshal, deputize, or otherwise employ other persons, or to do whatever else he may deem necessary for the purpose of meeting the emergency. The

34. Charter of the City and County of San Francisco, res. ch. 273, \& 3.100, 1971 Cal. Stats. 4602.

35. See Proclamation by Mayor Joseph L. Alioto, supra note 4. Mayor Alioto's action, by suspending the normal wage and civil service system, arguably subjected the City and County of San Francisco to the Meyers-Milias-Brown Act, which establishes minimum "meet and confer" requirements for those cities in California that have recognized public employee labor organizations but do not have established "merit systems," "civil service systems," or "other methods of administering employer-employee relations." CAL. Gov't Code $\$ 3500$ (West Supp. 1976).

If the Meyers-Milias-Brown Act applied, Mayor Alioto's settlement may have violated the provision requiring parties to a labor agreement to prepare a written memorandum of understanding for presentation to "the governing body or its statutory representative for determination." CAL. Gov'T CODE $\S 3505.1$ (West Supp. 1976). Section 3505.1, however, is probably inapplicable to emergencies declared by municipal executives pursuant to express charter provisions. Although the drafters did not explicitly consider executive emergency action, they did exempt from the notice and meeting re. quirements emergency ordinances, rules, resolutions, or regulations adopted by "governing bodies," "boards," or "commissions." CAL. Gov'T CODE $\$ 3504.5$ (West Supp. 1976). There is no reason to suspect that the legislature intended a different approach to valid emergency actions taken by municipal executives. 
mayor may make such studies and surveys as he may deem advisable in anticipation of any such emergency. ${ }^{36}$

California courts considered the meaming and scope of this provision in only one pre-1975 case. In Mullins $v$. Henderson, ${ }^{37}$ the Mayor of San Francisco declared a public emergency under section 25 of the 1932 Charter, the identically worded predecessor of section 3.100. The declaration was based on the fear that employees of a private railroad about to be acquired by the San Francisco Municipal Railway would seek better-payimg jobs in private industry rather than work for the City and County of San Francisco at beginner's pay. Such a response would have created a labor shortage that could have seriously disrupted public transportation during a period when San Francisco was a major military port and a center of war industry. Pursuant to his declaration, the Mayor "suspended" all contrary charter provisions and civil service regulations and granted the new employees full seniority with the resulting higher salaries. ${ }^{38}$ Three inembers of the Civil Service Commission, the Commission's executive officers, and a taxpayer intervenor challenged the Mayor's emergency declaration and subsequent actions as beyond the power conferred by the emergency provision of the charter. The trial court upheld both the Mayor's declaration and his subsequent actions, and the California Court of Appeal for the First District affirmed.

In reviewing the validity of the Mayor's emergency declaration, the court of appeal in Mullins rejected the arguinent that the term "public emergency" as used to the charter referred only to physical exigencies such as boinbings or natural disasters. To support its approach, the court cited cases imvolving "emergency" legislative appropriations for welfare purposes, ${ }^{30}$ "emergency" defenses to tort claims, ${ }^{40}$ and "emergency" public contracts entered into without competitive bidding. ${ }^{41}$ The court concluded that although an einergency involves an unforeseen event requiring immediate action, nothing in the cases suggests that the term is limited to particular kinds of sudden occur-

36. Charter of the City and County of San Francisco, res. ch. 273, $\$ 3.100,1971$ Cal. Stats. 4601-02 (amended 1975).

37. 75 Cal. App. 2d 117, 170 P.2d 118 (1st Dist. 1946).

38. Id. at 119-21, 170 P.2d at 121-22; S.F. Examiner, Aug. 8, 1944, at 1, col. 1. For a discussion of the exercise of emergency powers by the Lieutenant Governor of British Columbia to "acquire" private transportation facilities for public use and order strikers back to work, see Trevino, Governmental Emergency Powers-The Need for Interpretation, 1 U.B.C.L. REv. 67 (1959).

39. County of Los Angeles v. Payne, 8 Cal. $2 d$ 563, 66 P.2d 658 (1937).

40. Fennessey v. Pacific Gas \& Elec. Co., 20 Cal. 2d 141, 124 P.2d 51 (1942); Mason v. Crawford, 17 Cal. App. 2d 529, 62 P.2d 420 (3d Dist. 1936).

41. Los Angeles Dredging Co. v. City of Long Beach, 210 Cal. 348, 291 P. 839 (1930). 
rences. ${ }^{42}$ The court of appeal in Verreos, which did not directly discuss the issue, nonetheless necessarily agreed with the broad Mullins interpretation of "public emergency" by sustaining the validity of Mayor Alioto's actions.

This aspect of the Mullins and Verreos decisions is sound. In addition to judicial authority, ${ }^{43}$ legislative precedent of the San Francisco

42. 75 Cal. App. $2 \mathrm{~d}$ at 127,170 P.2d at 125 . Although no reported California case considers the meaning of the word "emergency" in the context of labor strife between a city and its public safety employees, courts in other jurisdictions have confronted questions involving the use of emergency provisions by city officials in order to prevent labor shortages in police and fire services.

In Baxter v. City of Philadelphia, 426 Pa. 240, 231 A.2d 151 (1967), the Philadelphia Civil Service Commission had promulgated an emergency regulation that lengthened the required work for police officers from 5-day, 40-hour work weeks to 6-day, 48-hour weeks. The Mayor of Philadelphia, declaring that an emergency existed "affecting the public health or safety" within the meaning of the city charter, made the emergency regulation effective immediately instead of allowing the normal 30-day period before new regulations were to take effect. Police officers challenged the Mayor's declaration, alleging that no state of emergency existed. The trial court found for the defendants, and the plaintiffs appealed.

The Supreme Court of Pennsylvania began its analysis by noting that the city charter "imposes a heavy duty on any party who wishes to attack the validity of this declaration." Id. at 250,231 A.2d at 157 . The court stated the vague notion that "insofar as it involves a question of fact," the finding of the trial court will not be disturbod on appeal if "based on sufficient evidence." Id. at 250,231 A.2d at 158. Exactly what aspects of the lower court's findings were sufficiently factual so as to trigger only limited appellate review was not explored, nor was there any discussion of why the plaintiff had a heavy burden in attacking the Mayor's action. Using these hazy standards, the court affirmed the judgment of the trial court. Noting that it was "a matter of simple arithmetic" that the shift from a 48- to a 40-hour week without a corresponding increase in overtime or personnel would reduce service hours by 20 percent, the court declared that "it takes little imagination to suggest that such a reduction in coverage posed dangers to public safety." Id. at $251,231 \mathrm{~A} .2 \mathrm{~d}$ at 158 . The court observed that although no problems were experienced during a previous 1-week period in which the shorter hours were actually in effect, crime deterrence might nevertheless have been undermined in the future as the fact of lesser police coverage became known to criminals. Id.

Cf. Crane v. City of New York, 185 Misc. 456, 57 N.Y.S.2d 251 (Sup. Ct. 1945), aff'd, 270 App. Div. 930, 62 N.Y.S.2d 617, aff'd, 296 N.Y. 717, 70 N.E.2d 538 (1946) (no distinction between energency caused by unusually large and widespread conflagration and potentially dangerous condition caused by labor shortage in fire department during the war). But see New Orleans Fire Fighters Local 632 v. City of New Orleans, 204 So. 2d 690 ( $\mathrm{La}$. Ct. App. 1967) (holding a threatened walkout by firefighters not an emergency but an aggravation of a chronic condition). See also Olshock v. Village of Skokie, 411 F. Supp. 257 (N.D. Ill. 1976), where the court held that an emergency situation brought about by a police strike justified prehearing suspension of police officers.

43. The Mullins court stretched the reach of judicial precedent by citing cases decided after the charter provision in issue was drafted. Judicial authority before 1931, however, also broadly construed the term "emergency" in the municipal context. See, e.g., People v. La Fetra, 230 N.Y. 429, 130 N.E. 601 (1921) (upholding emergency rent control law); In re Municipal Fuel Plants, 182 Mass. 605, 66 N.E. 25 (1903) (lack of fuel supply sufficient emergency to allow municipal government to establish 
Board of Supervisors supports an expansive construction of the term "public emergency." In the winter of 1921-22, for example, the Board passed an emergency appropriation to provide public works employment for unemployed ex-servicemen. ${ }^{44} \mathrm{~A}$ broad interpretation is likewise reinforced by the charter's legislative history: the charter was drafted and approved when the nation was in the throes of the Great Depression, an era when relief programs and proposals were popularly characterized as emergency measures. ${ }^{45}$ Moreover, the charter drafters used the term "public emergency" in section 25 rather than the more restrictive language found in other municipal charters such as "extraordinary epidemic or any disaster such as flood, fire, or earthquake."46

\section{B. Judicial Review of the Emergency Declaration}

A more questionable feature of the Mullins and Verreos opinions is their approach to the scope of judicial review to be applied to a municipal executive's declaration of emergency. ${ }^{47}$ In Mullins, the court stated that the question of whether a public emergency existed "is one of fact to be determined by the trial court." 48 The court then conducted a detailed canvass of the evidence before upholding the trial court's conclusion that the Mayor's declaration of emergency was justified under the charter. By so doing, the Mullins court implied that the question of whether an einergency actually existed may be subject

municipal fuel plants). See also Burke \& Patton, The Effect of Emergency Upon the Police Powers of a City, in The Municipalities AND THE LAW IN Action, 1941, at 150 (C. Rhyne, ed. 1942); Block v. Hirsch, 256 U.S. 135 (1921) (upholding an emergency provision in the District of Columbia allowing a tenant, under certain circumstances, to hold over after the expiration of a lease).

44. Report of the Mayor's Unemployment Committee of the City and County of San Francisco, Winter 1921-1922, at 12 (unpublished manuscript in San Francisco Public Library).

45. See generally Clark, Emergencies and the Law, 49 PoLITICAI SCI. Q. 268 (1934); Maurer, Emergency Laws, 23 GEo. L.J. 671 (1935).

46. See Charter of the City of Chico, ch. 12, art. 4, \& 20, 1923 Cal. Stats. 1447; Charter of the City of Stockton, ch. 2, art. 4, § 14, 1923 Cal. Stats. 1337; Charter of the City of Visalia, ch. 13, art. 6, \& 6, 1923 Cal. Stats. 1467.

47. Section 3.100 of the San Francisco Charter does not explicitly indicate the roles of the judicial and political branches of government in determining whether a public emergency exists. More explicit charter guidance would have been helpful. For instance, the 1921 Fresno Charter states that the Mayor "in time of public danger, of which he shall be the judge," may exercise ennergency powers. Charter of the City of Fresno, ch. 6, § 23, 1921 Cal. Stats. 1834. On the other hand, the 1931 San Diego Charter declares that the charter definition of what constitutes an emergency when the local legislature passes an urgency measure "shall be strictly construed by the courts." Charter of the City of San Diego, ch. 47, 17,1931 Cal. Stats. 2857. Because of the lack of specificity in the San Francisco Charter, however, courts must formulate a distribution of power in the emergency context that is consistent with the general framework of government established by the charter.

48. 75 Cal. App. $2 \mathrm{~d}$ at 121,170 P.2d at 122. 
to de novo examination in superior court. In Verreos the court of appeal was more explicit, declaring that "the trial court must determine for itself, based upon the evidence presented, whether an actual emergency existed at the time of the declaration." ${ }^{\prime 4}$

\section{Review of State Legislative Urgency Declarations}

The broad scope of review in Mullins and Verreos contrasts sharply with the standard of review applied by California courts when the state legislature passes an urgency measure under the California Constitution. An urgency measure is defined as a statute "necessary for inmediate preservation of the public peace, health and safety.":00 Such legislation truncates the citizens' right of referendum by making legislative action effective immediately upon enactment. ${ }^{51}$ In this context, the statement of facts in the state legislature's preamble is conclusive upon the courts. The legislature's determination that the facts present an emergency is invalid only if it "appears clearly and affirmatively from the legislature's statement of facts that a public necessity does not exist." ${ }^{\text {"22 }}$ The trial court in such cases is confined to resolving the legal question whether the statement of facts cannot support the legislature's conclusion that an emergency exists.

The California Supreme Court expressed its rationale for this limited review in Davis v. County of Los Angeles, ${ }^{63}$ an action challenging the validity of an urgency measure passed by the state legislature authorizing local school districts to establish retirement systems for teachers. The court recognized that the California Constitution vested the legislature with power to pass emergency legislation. In the absence of explicit state constitutional authorization for judicial review, the court declared that it was the legislature's task to "determine whether a given law is necessary for the preservation of public health, peace, and safety." ${ }^{54}$ The court cited with approval the language of the Prohibitory Amendment Cases ${ }^{55}$ in which Justice Brewer, later to

49. 63 Cal. App. 3d at 104, 133 Cal. Rptr. at 660.

50. CAL. CoNST. art. IV, $\S 8$.

51. Normally, state statutes do not take effect until 90 days after passage in order to allow citizens an opportunity to challenge the action of the legislature through the referendum process. See CAL. CoNST. art. IV, $\$ 8$.

52. Davis v. County of Los Angeles, 12 Cal. 2d 412, 422, 84 P.2d 1034, 1040 (1938). Accord, Stockburger v. Jordan, 10 Cal. 2d 636, 76 P.2d 671 (1938); Azevedo v. Jordan, 237 Cal. App. 2d 521, 47 Cal. Rptr. 125 (1st Dist. 1965); Behneman v. Alameda-Contra Costa Transit Dist., 182 Cal. App. 2d 687, 6 Cal. Rptr. 382 (1st Dist. 1960).

53. 12 Cal. $2 \mathrm{~d} 412,84$ P.2d 1034 (1938). See also Morgan v. City of Long Beach, 57 Cal. App. 134, 207 P. 53 (2d Dist. 1922).

54. $12 \mathrm{Cal} .2 \mathrm{~d}$ at $420-21,84 \mathrm{P} .2 \mathrm{~d}$ at 1039 .

55. 24 Kan. 706 (1881). 
become a Justice of the United States Supreme Court, wrote for the Kansas Supreme Court that such questions of policy "are wrought out and fought out in the legislature and before the people." 56 The Davis court could well have quoted further language from the opinion, where Justice Brewer declared: "The judge who casts his individual opinions of wisdom or policy into the decision . . . simply usurps a prerogative never committed to hin in the wise distribution of duties made by people in their fundamental law."57

\section{Review of Municipal Legislative Emergency Declarations}

Although some state courts have extended the Davis approach to emergency legislation enacted by municipal legislatures, ${ }^{58}$ California courts consistently have applied a less deferential standard of review to municipal legislative declarations of emergency. In San Christina Investment Co. v. City \& County of San Francisco, ${ }^{50}$ the supreme court sustained a challenge to a 1910 einergency ordinance passed by the San Francisco Board of Supervisors that attempted to suspend a tax limitation provision in the charter in order to raise funds for reconstruction following the 1906 earthquake and fire. Finding that the Board had attempted invalidly to "nurse" the emergency over a period of years in order to evade explicit cliarter limitations on municipal authority, the court held that the trial court could review both the recited facts and the conclusions drawn in an ordinance passed by a municipal legislature declaring an emergency. ${ }^{60}$ This view was reaffirmed in Davis, where the supreme court noted that judicial restrictions not explicitly found in the state constitution may be imposed on a municipal legislature's declaration of emergency. ${ }^{61}$

Even if it is established that both the recited facts and the conclusion of emergency drawn from thein by a inunicipal legislature are subject to state court review, the burden of proof nevertheless rests with the party attacking the validity of the declaration. In Los Angeles

56. Id. at 706 .

57. Id. at 706-07.

58. See, e.8., City of Phoenix v. Landrum \& Mills Realty Co., 71 Ariz. 382, 227 P.2d 1011 (1951); Lyman v. Town of Bow Mar, 533 P.2d 1129 (Colo, 1975); Dubyak v. Kovach, 164 Ohio St. 247, 129 N.E.2d 809 (1955); Stern v. City of Spokane, 60 Wash. 325, 111 P. 231 (1910). See also 5 E. McQuillin, Municipal Corporations $\S 15.40$ n.42 (rev. vol. 1969).

59. 167 Cal. 762, 141 P. 384 (1914).

60. Id. at 770-74, 141 P. at 387-88. See also Burr v. City \& County of San Francisco, 186 Cal. 508, 199 P. 1034 (1921); Josselyn v. City \& County of San Francisco, 168 Cal. 436, 143 P. 705 (1914); Spreckels v. City \& County of San Francisco, 76 Cal. App. 267, 244 P. 919 (1st Dist. 1926).

61. 12 Cal. $2 \mathrm{~d}$ at $421,84 \mathrm{P} .2 \mathrm{~d}$ at 1040. 
Dredging Co. v. City \& County of Long Beach, ${ }^{62}$ the court upheld challenged municipal contracts awarded without competitive bidding in part on the grounds that water pollution, which resulted from performance of the dredging contracts, fell within the scope of a charter provision allowing the letting of public contracts without competitive bidding in times of emergency. The opinion stated that a declaration of emergency by a municipal legislature, though not conclusive, is "prina facie evidence of the existence of an emergency and places the burden on the party attacking the declaration." ${ }^{\circ 3}$

California courts have not explaimed why municipal emergency declarations are subject to de novo judicial review when state legislative urgency declarations are upheld by state courts unless "it appears clearly and affirmatively from the legislature's statement of facts that a public necessity does not exist." ${ }^{44}$ There are at least two possible rationales. A municipal declaration of emergency may have greater political consequences than the exercise of urgency powers by the state legislature. In San Christina, for example, the exercise of emergency power would not only have allowed otherwise normal municipal legislative action to take effect immediately upon passage by the municipal legislature and approval by the Mayor. The einergency declaration in San Christina, if valid, would have empowered the municipal legislature to levy taxes im excess of normal charter limitations. ${ }^{65}$ Arguably, this consequence so substantially increases the power of municipal government over its citizens as to require more stringent judicial review than when the only result of the exercise of emergency power is the elimination of the citizen's right to referenduin. In Verreos, however, the emergency declaration laid the foundation for a shift in the distribution of municipal power, not a substantial expansion of municipal power.

It may also be argued that more stringent judicial review of municipal emergency declarations is justified because of the greater degree of abuse and corruption of power that has historically occurred in local government as compared to state government. Undeniably, the history of local government in America ${ }^{66}$ - and in San Francisco ${ }^{67}$ does reveal corruption and abuse of power by local politicians. Fear

62. 210 Cal. 348, 291 P. 839 (1930).

63. Id. at $358,291 \mathrm{P}$. at 844 . (1938).

64. Davis v. County of Los Angeles, 12 Cal. 2d 412, 422, 84 P.2d 1034, 1040

65. See text accompanying notes 59-60 supra.

66. See Bruff, Judicial Review in Local Government Law: A Reappraisal, 60 Minn. L. Rev. 669, 671-72 (1976); Note, City Government in the State Courts, 78 Harv. L. Rev. 1596, 1601 (1965). See also 2 E. MCQuillin, Municipal CorporaTIONS \$§ 9.10-.11 (rev. vol. 1966).

67. See W. Bean, Boss Ruef's San Francisco (1972); P. Steffens, The AutoBIOGRAPHY OF LINCOLN STEFFENS 570-74 (1931). 
of municipal corruption where contracts were awarded without normal bidding procedures was one justification for de novo judicial review in Los Angeles Dredging. ${ }^{68}$ It is questionable, however, whether such concern over irresponsible political behavior by local politicians is as valid today as it was 50 years ago. ${ }^{68}$ Furthermore, it is not clear that state government has been any more free of corruption and abuse than local government. ${ }^{70}$

\section{The Proper Scope of Review for Municipal Emergency Declara- tions}

Even if a declaration of emergency under the unamended section 3.100 of the San Francisco Charter sigmificantly expanded municipal power, and even if corruption and abuse of local power occur more often in local than in state government, it does not follow that Mayor Alioto's declaration of emergency should have been subjected to de novo review when challenged in state court. An approach to judicial review that vests in the state courts the power to determine whether an eniergency "actually exists" under a municipal charter ignores the judiciary's lack of institutional competence to identify and weigh the political considerations required to decide the question. How would a state court determine the nature of the threat to public safety presented by the San Francisco police and fire strike? Could would-be perpetrators of crime be polled to ascertain their future behavior should the strike continue? Could expert sociologists collect data measuring that the public sense of security and project the level of citizen fears in the future should a number of contingencies occur? Where the psychology of the body politic is crucial, as it often is in energency situations, it is more desirable that

68. See text accompanying notes 62-63 supra.

69. See Advisory Comm'N on Intergovernmental Relations, State Constitutional and Statutory Restrictions upon the Structural, Functional, and PerSONNEL Powers of LOCAL GOVERNMENT 72 (1962), cited in Bruff, supra note 66, at $687 \mathrm{n} .95$, where the Commission states:

The abuse by local government of broad powers troubles the Commission minimally. It is not currently widespread in any serious way. The fact that abuse conceivably might occur is no more reason to deny broad delegations of power than it is to deny a Boy Scout a knife because he might cut himself. Additionally, we are of the opinion that if a broad functional delegation of power is not a part of total power residing in the local governing body, it will be more responsive to popular control.

70. See L. Berg, H. HAHN \& J. Schmichiatser, Corruption in the American PoLITICAL SXSTEM 155 (1976), where the authors conclude that practices of the California legislature "really do not differ substantially from the 'shake down' practices of so-called less reformed political environments such as those of Chicago." For a summary of state legislative reactions to public criticism regarding the influence of lobbyists, see Council of State Governments, State Conflict of Interest/Financial Disclosure Legislation, 1972-75 (1975). 
factfinding be performed by elected politicians, rather than by judges removed from the realities of municipal politics.

Even if relevant social science data could be amassed and could survive evidentiary objections, ${ }^{71}$ how would a court harness such information into a judicial framework in order to decide whether an emergency "actually existed"? Suppose it could have been shown that a continued police strike im San Francisco would have meant a 75 percent probability of a 20 percent increase in the crime rate over a period of 2 weeks, or that the possibility of an earthquake occurring during the strike was very remote, but that if it occurred, there would be a substantial risk of widespread fires that, because of the strike, would inevitably lead to loss of life and destruction of property. What principle could a court apply in determining whether these "facts" are of sufficient gravity to constitute a "public emergency" under a charter provision? Citizens obviously value their own personal safety, but they also value the normal governmental processes that provide structured channels for imput into local decisionmaking. When these values conflict, resolution is better left to politicians, who are more responsive to the electorate than are the courts. The greatest protection of citizen interests may result if courts defer to branches of government influenced by public opinion and refrain froin imterjecting judicial perceptions of the public good through judicial review. ${ }^{72}$ If mistakes of judgment by politicians occur, the voters can retaliate by voting politicians out of office. $^{73}$

Arguably, such deference by courts to political branches of government borders on a "political questions" doctrine im the context of municipal government declarations of emergency. But judicial deference does not necessarily mean extraordmary abstention from exercising the powers of judicial review; rather, it calls for the ordinary

71. See generally Note, Opinion Polls and the Law of Evidence, 62 VA. L. REv. 1011 (1976).

72. See also Jackson, The Task of Maintaining Our Liberties: The Role of the Judiciary, 39 A.B.A.J. 961, 964 (1953). Consider also Professor Wechsler's famous comments in the context of constitutional adjudication:

A principled decision . . . is one that rests on reasons with respect to all the issues in the case, reasons that in their generality and their neutrality transcend any immediate result that is involved. When no sufficient reasons of this kind can be assigned for overturning value choices of the other branches of the Government or of a state, those choices must, of course, survive.

Wechsler, Toward Neutral Principles of Constiutional Law, 73 HARv. L. REv. 1, 19 (1959).

73. See text accompanying note 7 supra. But see Comment, The Scope of the Initiative and Referendum in California, 54 CALIF. L. REv. 1717, 1740 (1966), where the author argues that legislative supermajorities and the ultimate responsibility of the legislators to the public at the polls offer insufficient protection against legislative abuse. See also C. Antieau, Municipal Corporation LaW $\$ 4.38$ (1975). 
respect by courts for the political domain. ${ }^{74}$ The court would not be abstainimg from charter imterpretation, but would exercise the power of judicial review in determining the distribution of emergency powers. A court that fimds primary responsibility for decisionmaking in the political branches of government is not abdicating judicial responsibility but affirming it.

A case could be made for more stringent review of executive than of legislative municipal declarations of emergency. No California case, imcluding Mullins and Verreos, considers whether the distinction between executive and legislative declarations of emergency is relevant in determining the scope of judicial power. Two related arguments could support the view that courts should apply a more stringent standard to review of executive emergency declarations. First, the municipal executive may represent a narrower cross section of imterest groups than the legislative body, thus increasing the risk of a distorted weighing of political values. Second, determinations of emergency by a municipal executive may more likely be made in closed discussion and therefore may be less responsive to the restraining influence of public debate. There is hittle likelihood, however, that the state judiciary, whose members are generally drawn from a narrow cross section of society, will be nuore representative of the community than the municipal executive. Moreover, the judiciary is designed institutionally to be nuore detached from public opinion than other branches of government. ${ }^{75}$ Thus, strimgent court review of declarations of einergency by municipal executives is not likely to make emergency decisionmaking more representative of community values.

\section{The "Fraudulent, Arbitrary, or Capricious" Standard}

A less intrusive degree of judicial review of emergency declarations by municipal bodies than trial de novo therefore seems desirable.

74. See Henkin, Is There a "Political Question" Doctrine?, 85 YALE L.J. 597, 601 (1976). The deference-to-political-branches argument, of course, is not applicable where individual rights are at stake.

75. Although it is true that judges are elected officials, CAI. CoNST. art. $6, \S 16$, the Governor appoints judges to fill vacancies when they occur, subject to confirmation by the Commission on Judicial Appointments, whose members are the Chief Justice of the Supreme Court, the Attorney General, and the Presiding Justice of the Court of Appeal for the affected district. In a 1965 survey, 85 percent of the judges responding indicated that they originally took office by appointment. When these appointed judges run for reelection, few are opposed and those that are opposed are rarely defeated. B. Cook, The Judicial Process in California 47 (1967). Even when a judge is opposed in an election, the issues are sharply limited, because a candidate for judicial office "should not announce his views on disputed political or legal issues." CalIForNIA CODE OF JUdicial CONDUCt CANon 7(B)(1)(c). Thus, judicial cainpaigns usually focus on qualifications for office and reputation in the community rather than on political issues. 
One possible standard of review is for courts to examine municipal declarations of emergency only to consider whether the finding of emergency by the local entity was fraudulent, arbitrary, or capricious. ${ }^{70}$ Fraud, of course, would arise when the decisionmaking body overtly and materially misrepresents the actual conditions upon which the finding of emergency is based. ${ }^{77}$ Though it is difficult to develop standards for determiming whether a finding of emergency is arbitrary or capricious, relevant factors im the determination would include the gravity of the difficulty facing the municipality, the potential adverse effect on citizens if emergency powers are not exercised, the lack of present alternatives to the use of emergency powers, and the potential ability of local government officials to plan in advance to cope with the difficulty without resorting to emergency powers.

The "fraudulent, arbitrary, or capricious" standard of review would allow state court intervention when the political branches of municipal government declare emergencies based on boilerplate or fraudulent factual recitals, when emergency powers are invoked by local government ouly to deal more conveniently with day-to-day governmental problems, or when exercises of emergency power are motivated by personal gain rather than community well-being. The proposed standard thus squarely meets the concerns that apparently underlie judicial review of municipal declarations of emergency without imposing highly intrusive de novo review on the political branches of government.

Applying the fraudulent, arbitrary, or capricious standard to the situation presented by the San Francisco police and fire strike, there seems little question but that Mayor Alioto's declaration of emergency should not have been overturned by a reviewing court. The risk to public safety caused by lack of police and fire protection was at least arguably substantial. While there might have been other possible approaches to the problem, including the invocation of emergency provisions in the California Government Code as advocated by the Board of Supervisors, ${ }^{78}$ Mayor Ahoto's declaration of emergency had a rational basis. ${ }^{79}$ Although Mayor Alioto may not have at all times

76. See Cal. Water Code $\$ 358$ (West 1970), where court review of determinations of water shortage emergencies by government authorities is limited in such a manner.

77. See W. Prosser, HANDBOOK ON THE LAW OF TORTS $\S 105$, at $685-86$ (4th ed. 1971).

78. See note 30 supra and accompanying text.

79. The gravity of the situation was summarized in Mayor Alioto's Proclamation, supra note 4. The Mayor noted that police officers and civilians were on strike, that only emergencies of the highest priority were being answered by the police, that firefighters had received strike sanction from the San Francisco Labor Council, that picketing was threatening the city's firefighting capability and was raising the possibility of a widespread breakdown in municipal services, and that the Board of Supervisors had 
fully disclosed his intended actions to the Board of Supervisors, ${ }^{80}$ the Mayor's lack of candor does not rise to a fraudulent declaration of the existence of an einergency, particularly when the Board of Supervisors had approved an emergency ordinance only 2 days before. ${ }^{81}$

The foregoing analysis, however, does not end the inquiry. Once the Mayor has declared an emergency, the question of what powers he may exercise to meet the crisis remains. In resolving the strike emergency, Mayor Alioto "suspended" the salary provisions of the charter and attempted umilaterally to appropriate funds from the public purse to pay for salary increases under his settlement. The Mayor took this action despite express opposition from the Board of Supervisors, which was in session throughout the crisis. They key inquiry is whether the unamended emergency provision conferred such power on the Mayor of San Francisco under these circumstances.

III

The Scope of Mayoral Emergency Power

\section{A. Judicial Review of the Scope of Mayoral Emergency Authority}

Compared to the question whether an emergency actually exists, the question whether the Mayor exceeded his authority under the charter is more susceptible to judicial analysis. Principles of municipal government and of statutory construction can be applied to determine the scope of mayoral power. Although judicial demarcation of the boundaries of mayoral authority may at times be difficult, no thorny calculation of the gravity of risk presented by a given situation is needed nor is any balancing of noncharter or nonhistorical political values required to resolve the question.

Amenability to the judicial mode of analysis does not necessarily mean, however, that the state judiciary should have the power to decide the question. The best resolution, at least in the context of local gov-

called for the intervention of outside law enforcement personnel, thereby raising the possibility of confrontation between outside law enforcement officers and striking San Francisco police.

80. For instance, when negotiating with police and fire labor leaders, Mayor Alioto agreed to use his emergency powers to provide amnesty for strikers. The agreement was embodied in a handwritten memorandum signed by the Mayor and dated 2:30 a.m., August 21, 1975. A copy of this memorandum was filed with the court in San Francisco Fire Fighters Local 798 v. City \& County of San Francisco, Civil No. 700-977 (Super. Ct. San Francisco, Mar. 30, 1976), and is on file at the California Law Review. The Mayor did not mention this amnesty agreement in the one-page Proposed Settlement that he presented to the Board of Supervisors on August 21. See text accompanying notes 33-34 supra.

81. See text accompanying note 30 supra. 
ernment, may result where the courts stay out of such controversies altogether and allow the political branches of government to fight out an acceptable distribution of power between themselves. This approach would not leave the legislative branch without recourse against the executive, but would require the legislature to engage in political struggle to maintain its power position. Far from being undesirable, such a struggle may encourage political accountability. Indeed, after Mayor Alioto's settlement, the Board retaliated by proposing four charter amendments that sharply limited police and fire salaries, required automatic termination of strikers, instituted at 14-hour work schedule in the fire services, and curtailed the power of the Mayor in public emergencies. $^{82}$ In passing these charter amendments by overwhelming margins, the voters declared the Board of Supervisors the victor in the power struggle.

But something more is at stake than the protection of naked political rights. ${ }^{83}$ Judicial nonintervention in cases like Verreos would mean that a municipality may be deprived of funds appropriated by a Mayor acting outside official charter authority if the legislative body is politically unable or unwilling to prevent unauthorized appropriations. Such a result would run counter to the spirit of section 526a of the California Code of Civil Procedure, which provides for taxpayer suits to enjoin "any illegal expenditure" or public funds. ${ }^{84}$ Recitation of this statute does not conclusively establish whether state courts are empowered to decide what is "legal" in the context of distribution of emergency powers, but the provision does reflect the legislature's view that judicial policing - of municipal action is needed to supplement the political process. Section 526a, which California courts have declared is to be liberally con-

82. See note 7 supra.

83. See Malone v. Superior Court, 40 Cal. 2d 546, 254 P.2d 517 (1953) (where public property rights, as well as political rights, were involved, the court intervened in a dispute over appointment of members to the Democratic County Central Committee).

Although the Board of Supervisors, named as a party defendant by taxpayer Verreos, attempted to intervene as a plaintiff against the City and County of San Francisco, the court of appeal held that the Board had no cause of action. The court stated that "the board of supervisors, as such, was in no sense aggrieved by the judgment upholding Alioto's actions ...." Verreos v. City \& County of San Francisco, 63 Cal. App. 3d at 94, 133 Cal. Rptr. at 654.

The Board of Supervisors, of course, was capable of independent retaliation against the Mayor and against the police and fire associations without the aid of the judiciary. Immediately after Mayor Alioto's attempted settlement, the Board reduced budget allocations in both the police and fire departments, and eliminated 53 unfilled positions. See Two Case Studies, supra note 7, at 22.

84. Cal. Crv. Proc. Code $\$ 526 a$ (West 1970) (emphasis added). For a general survey of taxpayer suits, see Note, Taxpayers Suits: A Survey and Summary, 69 YaId L.J. 895 (1960). 
strued in order to achieve its remedial purpose,${ }^{85}$ has been held to provide a cause of action for taxpayers seeking to prevent unauthorized payment of salaries. ${ }^{86}$ Regardless of the appropriate result in the absence of this statute, section 526a appears to allow a taxpayer, but not the Board of Supervisors, to seek judicial intervention when a municipal officer acts outside the scope of charter authority in appropriating funds.

\section{B. Judicial Approaches to Charter Interpretation}

California courts have consistently applied canons of statutory construction to mumicipal charters. ${ }^{87}$ One of the most frequently recited rules is that absent "plain meaning," courts are bound by legislative intent. ${ }^{88}$ Yet ascertaining legislative intent is an elusive process because of subjective elements in the inquiry, the very real possibility that legislators act with either no intent or with complex intent, and the large number of participants in the legislative process, who may be inotivated by a variety of different concerns. ${ }^{89}$ For these reasons, searches for legislative intent often may become exercises in rationalizing judicial policy preferences.

But statutory construction need not be a rudderless voyage into the recesses of an ill-defined legislative inind. More disciphned approaches are available ${ }^{80}$-those focusing on legislative precedent, and those utilizing principles similar to contract law in distilling objective meaning from the four corners of a legislative document. Such techniques of construction find sustenance only from the legislative document and identifiable historical facts, not from subjective and possibly unrepresentative statements of opimion.

85. See, e.g., Blair v. Pitchess, 5 Cal. 3d 258, 268, 486 P.2d 1242, 1249, 96 Cal. Rptr. 42, 49 (1971); Crowe v. Boyle, 184 Cal. 117, 152, 193 P. 111, 125 (1920).

86. City \& County of San Francisco v. Cooper, 13 Cal. 3d 898, 534 P.2d 403, 120 Cal. Rptr. 707 (1975); Briare v. Matthews, 202 Cal. 1, 258 P. 939 (1927); Brown v Boyd, 33 Cal. App. 2d 416, 91 P.2d 926 (1st Dist. 1939).

87. See, e.g., Hartford Accident \& Indem. Co. v. City of Tulare, $30 \mathrm{Cal} .2 \mathrm{~d} 832$, 186 P.2d 121 (1947); Braun, Bryant \& Austin v. McGuire, 201 Cal. 134, 255 P. 808 (1927); Laurent v. City \& County of San Francisco, 99 Cal. App. 2d 707, 222 P.2d 274 (1st Dist. 1950).

88. E.g., Stafford v. Realty Bond Serv. Corp., 39 Cal. 2d 797, 249 P.2d 241 (1952); People v. Valentine, 28 Cal. 2d 121, 169 P.2d 1 (1946). See also Cal. Crv. PROC. CODE \& 1859 (West 1970).

89. For a characterization of legislative intent as an idiom, if not elusive, see 2A J. Sutherland, Statutes aNd Statutory Construction $\$ 45.05$ (4th ed. 1973) [hereinafter cited as SUTHERLAND].

90. This is not to suggest that hearings and statements by key legislators should be ignored in determining legislative intent, but rather that these materials are often too ambiguous to be useful. The hazards of using legislative materials for charter interpretation are magnified because at least three bodies-a 15 -member Board of Freeholders (or the municipal legislature), the voters of the municipality, and the state legislature-will have considered and approved the lengthy charter document with literally 


\section{Legislative Precedent}

The California bench and bar too often fail to recognize that drafting a charter is a legislative process that, though influenced by conteinporaneous political reality, is controlled by its own precedents and traditions. ${ }^{91}$ Whenever a Charter Revision Committee or Board of Freeholders asseinbles to consider charter changes, experience under the previous charter is reviewed, ${ }^{92}$ as are attempts of other local legislatures to deal with similar problems. ${ }^{93}$ Proper construction of a charter provision, therefore, requires knowledge of legislative precedent - a body of law as relevant to questions of statutory construction as judicial precedent is to questions of common law.

hundreds of substantive provisions. CAL. CONST. art. XI, $\$ 8$. Even assuming, however, that such legislative materials can be probative and may be marshalled in a principled fashion as an aide to judicial decision, they are rarely available when questions of local government arise. For instance, although the Board of Frecholders that drafted the emergency provisions of the 1932 San Francisco Charter apparently kept minutes, the minutes could not be found by the Citizen's Charter Revision Committee that met in the late 1960's and early 1970's to consider drafting a new charter. Convcrsation with Timothy McDonnell, 1970-71 Chairman of the San Francisco Citizens' Charter Revision Committee (Sept. 4, 1976).

The only contemporary commentaries of analytic quality on the charter are $F$. Keesling, The San Francisco Charter of 1931 (1932), and P. Devine, The Adoption of the 1932 Charter of San Francisco (1933) (unpublished thesis in Doe Library, University of California, Berkeley). Keesling devotes only one brief paragraph to section 25 of the charter. See note 97 infra. Devine, who apparently had access to the minutes of the Board of Frecholders, simply notes that in case of emergency, the Mayor "has charge of all the departments of the city and county." Devine, supra, at 50.

91. For example, there is no meaningful analysis of charter precedent in Mullins v. Henderson, 75 Cal. App. 2d 117, 170 P.2d 118 (1st Dist. 1946). For a discussion of the application of legislative precedent generally, see Breitel, The Lawmakers, 65 CoLUM. L. REv. 749, 760 (1965). See also Riesenfeld, Law-Making and Legislative Precedent in American Legal History, 33 MiNN. L. REv. 103 (1949).

92. See, e.g., Report of the San Francisco Citizens' Charter Revision ComMITTEE TO THE BOARD OF SUPERVISORS (1969), contrasting proposed charter changes to earlier provisions.

93. For instance, nine municipal charters passed by California communities in the 10-year period between 1923 and 1933 have precisely the same mayoral emergency provision: "In case of riot, insurrection or extraordinary emergency, [the Mayor] shall assume general control of the city government and all of its branches, and be responsible for the suppression of disorders and the restoration of normal conditions." Charter of the City of Oroville, ch. 22, $\$ 1,1933$ Cal. Stats. 2914; Charter of the City of Redwood City, ch. 37, ₹ 14, 1929 Cal. Stats. 2185; Charter of the City of Burbank, ch. $15, \S 9,1927$ Cal. Stats. 2113; Charter of the City of Pacific Grove, ch. 54, $\$$ 12, 1927 Cal. Stats. 2334; Charter of the City of Porterville, ch. 27, \$ 19, 1927 Cal. Stats. 2182; Charter of the City of Monterey, ch. 32, 1 10, 1925 Cal. Stats. 1296; Charter of the City of Piedmont, ch. 24, $\$ 11,1923$ Cal. Stats. 1569; Charter of the City of San Mateo, ch. 4, § 11, 1923 Cal. Stats. 1280; Charter of the City of Santa Rosa, ch. 6, \& 11, 1923 Cal. Stats. 1303. The appearance of this cxact provision in numerous charters is not happenstance, but is conclusive evidence of the influence of charter precedent in the drafting of municipal charters in California. 
The first significant mayoral emergency provision appeared in the San Francisco Charter of 1900, which vested power in the Mayor to "take all proper measures for the preservation of public order and suppression of all riots and tumults, for which purpose he may use and command the police force." ${ }^{.94}$ The Board of Freeholders that drafted the Charter of 1932 expanded the Mayor's emergency powers in section $25,{ }^{95}$ later to appear as section 3.100 of the recodified Charter of 1971. Such a change in a charter provision generally does not spring full blown from theory, but is grounded im past events that demonstrate the madequacy of the earlier provision. ${ }^{96}$

One event may explain the expansion of mayoral emergency power in the 1932 Charter is the San Francisco earthquake and fire of April 1906. ${ }^{97}$ This catastrophe ${ }^{88}$ forced Mayor Eugene Schmitz to do more than merely command the police force to suppress the resulting tumult. He also closed saloons, took control of all personnel fighting the disaster, ordered the dynamiting of buildings to contam

94. Charter of the City and County of San Francisco (1900), art. 4, ch. 1, § 2, ch. 2, 1899 Cal. Stats. 269.

95. Charter of the City and County of San Francisco (1932), ch. 56, $\$ 25,1931$ Cal. Stats. 2993-94.

96. Cf. Crowe v. Boyle, 184 Cal. 117, 125, 193 P. 111, 114 (1920) (where the court noted that "It will be helpful in determining the intent of the people in adopting these charter provisions, to consider the history of the adoption .... Such history is uniformly considered in dealing with kindred subjects, such as the interpretation of constitutions."). Nevertheless, California cases often do not use this mode of analysis in charter interpretation. See, e.g., Mullins v. Henderson, 75 Cal. App. 2d 117, 170 P.2d 118 (1st Dist. 1946).

97. In the only comprehensive commentary by a participant who helped frame the 1932 Charter, Francis Keesling, Vice President of the Board of Freeholders and Chairman of the Drafting Committee, devoted only one paragraph to discussion of section 25 of the charter. After quoting the section verbatim, Keesling noted:

Studies made by the Commonwealth Club and other organizations, and experiences of the writer as commander of an artillery battalion following the earthquake and fire of 1906, einphasized the necessity of planning and preparation, in advance, for disaster organization and relief work if problems affecting public health, safety, and property are to be met in the most effective manner in the event of sudden disaster. The recent disaster in southern California further emphasizes the importance of study and preparation. It should not be neglected.

F. Keesling, The San Francisco Charter of 1931, at 68 (1932). Keesling's observations establish that at least one key member of the San Francisco Board of Freeholders adverted to the problems of the 1906 earthquake and fire in fashioming the emergency provisions of the 1932 Charter. Unfortunately, however, Keesling's commentary offers no elucidation of the meaning of the section 25 phrase empowering the Mayor to "do whatever else he may deem necessary for meeting the emergency." Charter of the City and County of San Francisco (1932), ch. 56, § 25, 1931 Cal. Stats. 2993.

98. It has been estimated that 498 persons were killed, 200,000 left homeless, 28,188 buildings destroyed, and over $\$ 500$ million of property lost. See C. O'CoNNor, F. McLean, H. ARtieda, J. Motley, J. Peixotto \& M. CoOldge, San Francisco ReLIEF SURVEY 45 (1913). 
fires, and formed a committee of leading citizens to manage the relief and recovery efforts. ${ }^{99}$ Though these actions were not legally challenged, none were founded on explicit charter authority.

This charter shortcoming was remedied with the adoption of section 25 of the 1932 Charter. Under this provision, the Mayor could "summon, organize, and direct the forces of any department in the city and county," 100 much as Mayor Schmitz had done in 1906 . Section 25 also expanded the earlier charter provision by allowing the Mayor "to summon, marshal, deputize, or otherwise employ other persons"101 to meet the emergency. The language of section 25 is broad enough to authorize the Mayor to employ and direct dynamiters, citizen volunteers, and military personnel-all of which Mayor Schmitz had done in $1906 . .^{102}$

Waterfront violence is a second feature of San Francisco history that suggested the inadequacy of the emergency provisions in the 1900 Charter. During dock strikes in 1901 and 1916, business leaders called on the Mayors of San Francisco to hire additional police officers to protect their property and to aid in breaking the strikes. ${ }^{103}$ Such hiring of additional personnel by the Mayor was not explicitly authorized by the 1900 Charter, and one of the business requests for additional police recognized that the laws of San Francisco might not "admit of the immediate augmentation of the police force . . ." "104 Although police intervention in labor struggles is usually poor policy, if not unconstitutional, ${ }^{105}$ the events nevertheless point to a general charter shortcoming-the mability of the executive to hire additional police to meet a sudden emergency. Section 25 of the 1932 Charter directly

99. Id. at 8, where it is said that the mayor "assumed almost absolute control of the city government for a time, superseding all departments and commissions."

100. Charter of the City and County of San Francisco (1932), ch. 56, \& 25, 1931 Cal. Stats. 2993.

101. Id. (emphasis supplied).

102. See E. Dolan, Disaster 1906: The San Francisco Earthquake and Firz 55 (1967) (military troops at Mayor's command); Id. at 66 (proclamation ordering saloons closed); Id. at 73 (use of dynamite ordered by Mayor and Fire Commissioners); Id. at 96 (proclamation ordering looters shot on sight); Id. at 140-42 (Mayor ordered dynamiting of buildings along Van Ness Avenue).

103. See Letter from George A. Newall, President of the Chamber of Commerce, to Mayor James Phelan, reprinted in S.F. Examiner, Aug. 10, 1901, at 3, col. 3. A similar request was made by the Chamber of Commerce to Mayor James Rolph. S.F. Examiner, July 6, 1916, at 3, col. 1. See generally B. Francis, A History of Labor on the San Francisco Waterfront (May 1934) (unpublished dissertation in Doe Library University of California, Berkeley).

104. See Letter from George A. Newall, supra note 103.

105. For an overview of the constitutional problems raised by police intervention in the 1934 strike, see H. Resner, The Law in Action Durung the San Francisco LONGSHORE AND MARITIME STRIKe OF 1934, at 53-57 (1936). 
resolved the problem by giving the Mayor explicit authority to employ "other" personnel. ${ }^{106}$

These historical events do not suggest a need to increase mayoral power in times of emergency in order to overcome opposition from other branches of government in the exercise of prescribed power under the charter. Rather, the events suggest a need-fulfilled by section 25-to provide charter authorization for quick executive action when other branches of government are incapable of acting or when alternative procedures are too cumbersome to allow for an adequate response to an emergency situation threatening life and property. In both the natural disaster and sudden violence contexts, there is often no time to assemble the Board of Supervisors and seek its approval of emergency actions. Where time is of the essence, such a requirement would not simply affect the distribution of municipal emergency power, but could prevent effective action by any municipal authority.

But where time limitations do not prevent full deliberation and decisionmaking by the Board of Supervisors, the legislative precedent found in the evolution of other sections of the San Francisco Charter suggests that the power of the purse remains with a functioning Board of Supervisors even during times of emergency. After the 1906 disaster, the voters approved a charter amendment that increased from $\$ 36,000$ to $\$ 100,000$ the amount that the Board could appropriate for "urgent necessities." ${ }^{107}$ The 1932 Charter expanded the Board's power by establishing an emergency fund from which appropriations could be made only with the recommendation of the appropriate department head and the Mayor, and the approval of three-fourths of the Board. ${ }^{108}$ Furthermore, during the Great Depression when it became desirable to reduce the wages of city employees in order to avoid worker layoffs and to maintain resources for relief purposes, the Mayor did not declare an emergency pursuant to section 25 , nor did he suspend other contrary provisions of the charter or reducc wages through mayoral proclamation. Instead, the Board of Supervisors proposed and the voters approved a charter amendment that authorized the Board of Supervisors, with a

106. This interpretation of section 25 is supported by subsequent events. During the summer of 1934, San Francisco experienced a longshore strike that eventually resulted in a crippling 3-day general strike. On July 14, 1934, Mayor Angelo J. Rossi declared a state of emergency pursuant to section 25. S.F. Exauniner, July 15, 1934, at 3, col. 1. Pursuant to the declaration, Mayor Rossi ordered the hiring and equipping of 500 additional police officers to help maintain order. S.F. Examiner, July 16, 1934, at 2, col. 2. See P. Eliel, The Waterrront and General Strikes, San Francisco, 1934, at 145-48 (1934). The Mayor also forned a Committee of 500, whose main function was to insure that the city had an adequate food supply during the general strike. S.F. Chrouicle, July 17, 1934, at 1, col. 4.

107. Charter of the City and County of San Francisco (1900), ch. 1, 1907 [2d Extra Sess.] Cal. Stat. 37 (amending ch. 1, art. III, ch. 1, \& 8, 1899 Cal. Stats. 258). 
three-fourths vote and concurrence by the Mayor, to declare an emergency under "extraordinary economic conditions" and to reduce salaries of public employees by specific amounts. ${ }^{109}$ The Board exercised this authority for several years during the Depression. ${ }^{110}$ Cumulatively, the charter history imdicates a desire by San Francisco freeholders to maintain the legislative powers of the Board of Supervisors in times of emergency when the Board is capable of exercising them. ${ }^{111}$

A survey of the evolution of the Charter of the City and County of San Francisco reveals a trend toward limiting the administrative, but not the legislative, powers of the Board of Supervisors. Although the 19th century San Francisco Charters vested nearly all municipal powers im the local legislature, corruption, political patronage, and inefficiency stimulated efforts to reforn the city government structure, and climaxed with the election of a reform Mayor in 1896 and the passage of a new charter that became effective in 1900 . The 1900 Charter, typical of those in the Progressive Era, strengthened the appointive powers of the Mayor, established the beginnings of a civil service system, and required the letting of public contracts to the lowest bidder. ${ }^{112}$

Because of continumg graft and apparent inefficiency, reform groups again sought charter change in the decades following the 1906 earthquake and fire. In 1916, a "good government" group suggested that charter change inight be necessary "to make the mayor definitely responsible for exercising administrative leadership," and "to inake the board of supervisors solely a legislative and reviewing body, which shall not exercise any admistrative function . . .."113 The reform effort peaked in 1926, when a committee sponsored by the San Francisco Bureau of Governmental Research advocated the city manager plan of government, and made a proposal that received the endorsement of the

108. Charter of the City and County of San Francisco (1932), ch. 56, $\$ 79,1931$ Cal. Stats. 3025-26.

109. Id. ch. 53, 1933 Cal. Stats. 3049-53 (amending ch. 56, \& 70, 1931 Cal. Stats. 3020-21).

110. See San Francisco Municipal Salaries, THE CTTY, May 14, 1934, at 2-14.

111. Similarly, the drafters of the Model Municipal Corporations Act vested the municipal legislature with power to make emergency appropriations upon a certificate signed by the Mayor and the Controller confirming the existence of an emergency. See National Municipal league, a Municipal Program, Report of a Committee of the National Municipal LEAgue 219 (1900).

112. Charter of the City and County of San Francisco (1900), ch. 3, art. II, ch. 2, 1899 Cal. Stats. 255 (requiring letting of contracts to the lowest bidder); $I d$. ch. 1 , art. IV, $\$ 4$, ch. 2, 1899 Cal. Stats. 269 (vesting appointive powers in the mayor); Id. ch. 1, art. XIII, ch. 2, 1899 Cal. Stats. 350-54 (establishing a civil service system).

113. Bureau of Municipal Research, Report on a SURVEY OF the Government of the City and County of San Francisco 45 (1916). 
San Francisco News. ${ }^{114}$ The Board of Freeholders elected in 1930 took a less drastic approach, however, by retaining the office of Mayor while creating the position of chief administrative officer, who, though appointed by the Mayor, was "to imsure a businesslike handling" of administrative matters. ${ }^{115}$ Although the character of these reforms suggests that one of the main goals of their proponents was to "take the politics out of local government"116 in the administrative context, the charter changes reflected no desire to limit the legislative powers of the Board of Supervisors. ${ }^{117}$

Although the distinction between legislative and administrative powers may often be blurred, California courts liave consistently characterized the setting of salaries for public employees as a legislative function. ${ }^{118}$ If legislative functions are defined as those that establish the broad outlines of government policy, ${ }^{119}$ the California decisions are

114. R. Stillman, Rise of THE CITY MaNager 25 (1974).

115. Levit, San Francisco's Unique Charter, 34 NaT'L Municipal Rev. 273, 276 (1945).

116. League of Women Voters, AN INTROduction to CtTy GovernMent-San FrANCISCo 6 (1967).

117. In fact, late 19th- and early 20 th-century reformers sought to increase the legislative powers of the council in order to strengthen the position of municipal government vis-à-vis the state legislature and to insure the nonpolitical nature of adininistrative functions performed by non-elected officials. See Goodnow, The Place of the Council and of the Mayor in the Organization of Municipal Government, in A MUNicipal Program, Report of a Committee of the National Municipal League 74-87 (1900). See also F. STEWART, A HAlF CENTURY OF MUNICIPAL REForm 38-42 (1950), where the author notes that municipal reformers sought to rehabilitate the council's legislative powers. Cf. Nanry, San Francisco Adopts a New Charter, 20 Nat'l Municipal Rev. 259, 260 (1931) (noting that the new charter "makes [the Board of Supervisors] definitely a legislative board, relieving it of all administrative duties."). See also 2 E. MCQUillin, MUNicipal CoRPorations $\$ 9.18$, at 656 (rev. vol. 1966), noting that the trend in mayoral power "seems to be not so much to increase the legislative power of the mayor, but to separate the legislative power from adininistrative functions, vesting the legislative power in a legislative department and the administrative functions in the executive branch...."

118. For a characterization of the setting of police salaries as a legislative function, see San Leandro Police Officers Ass'n v. City of San Leandro, 55 Cal. App. 3d 553, 127 Cal. Rptr. 856 (1st Dist. 1976). For cases involving public einployee salaries generally, see Alameda County Employees' Ass'n v. County of Alameda, 30 Cal. App. 3d 518, 106 Cal. Rptr. 441 (1st Dist. 1973); Francis v. Leavy, 131 Cal. App. 620, 21 P.2d 979 (1st Dist. 1933). Cf. CAL. Const. art. XI, § 5 (boards of supervisors in their respective counties regulate the compensation of all officers other than supervisors, district attorneys, auditors, and municipal court judges). The governing legislatibe body is generally vested with the power to fix salaries in other jurisdictions as well. See 4 E. MCQuillin, Municipal Corporations $\$ 12.177$ (rev. vol. 1968); E. Yokley, Municipal Corporations $\$ 347$ (1957); C. Elliott, Municipal CorporaTroNs $\S 222$ (3d ed. 1925).

119. This language represents a rewording of the standard definition that declares legislative those functions constituting "a declaration of public purpose" and "inaking provision for ways and means of its accomplishment". See McKevitt v. City of Sacramento, 55 Cal. App. 117, 124, 203 P. 132, 136 (1st Dist. 1921). 
on solid ground. The establishment of wage levels by local governments involves basic political decisions since an imcrease in public wages either affects the availability of funds for other needs or requires an increase in taxes or public indebtedness. ${ }^{120}$

The political impact of wage setting can be seen in Mayor Alioto's one-page summary of his proposed settleinent. The Mayor stated that "the difference between the Board's proposal and the settlement offer is $\$ 2,651,306$. When we deduct from that the wages not paid during the strike, that difference is approximately $7 \phi$ on the tax rate. We believe additional economies throughout the year in the Police Departinent, without inpairing services, can reduce the difference to zero."121 As phrased, the statement suggested that the policy implications of the wage settlement were mimimal or even nonexistent. But it implicitly conceded that the settlement would have an immediate inpact. If no economies were to be realized in other parts of the budget and there were to be no increase in borrowing, the tax rate would have to be increased by $7 \phi$ in order to finance the settlement. Any savings realized in the police departinent would have to be used to meet the cost of the wage increase and not for other police services, such as putting more patrol officers on the beats or providing increased police protection on public transportation. If it was inpossible to realize economies, and if a tax increase was not possible, other municipal services would have to be cut to finance the settlement. To allow the Mayor, even in times of emergency, to force these limited alternatives on municipal government is to intrude deeply into the general policymaking powers that the San Francisco Charters have always vested in the Board of Supervisors. ${ }^{122}$

\section{Textual Charter Analysis}

Although the legislative precedent mode of analysis focuses on the relationship between words of the provision to be construed and externalities, textual analysis concentrates solely on the relationships among the words in the charter. As in contract law, textual analysis attempts to discover objective meaning froin the words of the document-what would a reasonable legislator, given the document as a whole, have intended the words to signify? Although California courts have not

120. Cf. H. Wellington \& R. Winter, The Unions and the Cities 14 (1971) (suggesting that "low pay" for teachers may be a decision to exchange a reduction of quality of teaching or the quantity of teachers for higher welfare payments).

121. Proposed Tentative Settlement, supra note 3.

122. See, e.g., City \& County of San Francisco v. Boyd, 22 Cal. $2 d 685,140$ P.2d 666 (1943); Collins v. City \& County of San Francisco, 112 Cal. App. 2d 719, 247 P.2d 362 (1st Dist. 1952); Adams v. Wolff, 84 Cal. App. 2d 435, 190 P.2d 665 (1st Dist. 1948). 
emphasized the objective nature of the inquiry, it is well established that charters are to be construed in their entirety. ${ }^{123}$

In Mullins and Verreos, the courts rejected this approach, apparently relying instead upon the "plain meaning" rule of statutory interpretation. ${ }^{124}$ In Mullins, the court found it "clear from reading the words enployed in section 25 , that the powers granted thereby are very broad, and that there was no intention on the part of the freeholders who framed the section, nor the voters who adopted it, to place thereon ... narrow restrictions . . . "125 From this premise, the Mullins court, over a strong dissent by Justice Peters, concluded that the Mayor had the power unilaterally to grant full semiority to new city and county employees pursuant to his declaration of emergency in spite of specific charter provisions vesting such power in the Board of Supervisors. ${ }^{126}$ Similarly, the court in Verreos, noting that section 3.100 states that the Mayor shall have the power to do "whatever . . . he may deein necessary for the purpose of meeting the einergency," concluded that "it is apparent that this language grants extremely broad powers and discretion to the Mayor in a situation where an einergency exists."127

The situation in Mullins, however, is distinguishable from that presented in Verreos. The court in Mullins, although allowing the Mayor to assuine functions that under the charter were norinally vested in the Board of Supervisors, assumed that the Board was incapable of acting to meet the crisis. According to the court, "any atteinpt to follow the normal procedure" established by the charter "would have delayed the granting of parity pay for more than a year after the time of crisis," because the wage-setting provisions of the charter provided that "an ordinance fixing the compensation of any employee included in the schedule of compensations adopted subsequent to April 1, 1944 [including the employees of the private line soon to be inerged with

123. See, e.g., Weber v. County of Santa Barbara, 15 Cal. $2 \mathrm{~d} 82,98$ P.2d 492 (1940); Neuwald v. Brock, 12 Cal. 2d 662, 86 P.2d 1047 (1939); City of San Jose v. Lynch, 4 Cal. 2d 760, 52 P.2d 919 (1935).

124. The California Supreme Court applied the "plain meaning rule" in the context of charter interpretation in People ex rel. Woods v. Sands, 102 Cal. 12, 36 P. 404 (1894). The court stated: "When the intention of the legislature is so apparent from the face of the statute that there can be no question as to meaning, there is no room for construction." Id. at 16,36 P. at 405 . For other formulations of the rule, see 2A SUTHERLAND, supra note $89, \S \S 45.02,46.01,46.04$.

When judges properly apply the "plain ineaning rule," they are saying not only that a particular meaning of a statute is plain, but also that the statutory language is not reasonably capable of suggesting any other meaning. See Jones, The Plain Meaning Rule and Extrinsic Aides in the Interpretation of Federal Statutes, 25 WASH. U.L.Q. 2, 22 (1939).

125. 75 Cal. App. $2 d$ at 131,170 P.2d at 128.

126. Id. at $131-32,170$ P.2d at $128-29$.

127. 63 Cal. App. 3d at 108, 133 Cal. Rptr. at 663. 
the Municipal Railway] would not become effective until July 1, 1946."128

Whatever the validity of the "plain meaning rule" in Mullins, it is of no use in determining whether Mayor Alioto's action exceeded his authority in Verreos. Nothing in section 3.100, as it read in 1975, clearly allocated power between the Mayor and a functioning Board of Supervisors to alter the terms of public employment in times of emergency. Although the power granted by the unamended mayoral emergency provision may have been broad on its face, other sections of the charter that vested sole power in the Board of Supervisors to set salary levels for police and fire officers had an equally "plain meaning."120 Instead of fashioming an emergency provision that dealt with the necessarily unforeseeable with a strict rule susceptible of "plain meaning," the charter drafters more likely wrote a purposefully vague provision in order to allow case-by-case consideration of mayoral power. If so, the provision would require that the factual contours of a given situation be measured against the template formed by the charter's distribution of powers to determine whether mayoral action exceeded the scope of executive authority established in the charter.

\section{a. Powers of the Mayor}

Except for the amendment to the mayoral emergency provision, section 3.100 is the same today as in 1975. This section gives the Mayor responsibility for the enforcement of laws relating to the municipality, for the review and submission of the annual executive budget, and for the administration of all departments under those boards and commissions appointed by the Mayor, including the police and fire commissions. ${ }^{130}$ The Mayor, who has a seat on the Board of Supervisors but no vote, may veto Board action, subject to override by a two-thirds vote of the Board. The emergency provision invoked by Mayor Alioto was the ninth and last paragraph of the section, prior to the 1975 amendment. ${ }^{131}$

There are two features of section 3.100 relevant to the meaning of the unamended mayoral emergency provision. First, the powers of the Mayor are not general, but enumerated. The charter is so specific that it authorizes the Mayor, for instance, to appoint "an executive secretary, and one confidential secretary, and one stenographer." 132 There is not even a general statement conferring "executive powers" on

128. 75 Cal. App. 2d at 126, 170 P.2d at 125 .

129. Charter of the City and County of San Francisco, res. ch. 273, $\S 151,1971$ Cal. Stats. 4756.

130. Id. $\$ 3.100,1971$ Cal. Stats. 4600.

131. See note 32 supra and accompanying text.

132. Charter of the City and County of San Francisco, res. ch. 273, $\S 3.100,1971$ Cal. Stats. 4600. 
the Mayor, though the Mayor is described as "the chief executive officer ... upon whom process issued by authority of law shall be served."133 A sweeping interpretation of the unamended emergency provision would be inconsistent with such closely tailored mayoral powers. Second, the Mayor's formal legislative power, with the exception of the veto power, is limited to making submissions and reports to the Board of Supervisors, and reducing, but not adding, to expenditures approved by the Board. ${ }^{134}$ The absence of spending power casts doubt upon any interpretation of the unamended emergency provision that would allow the Mayor to make substantial appropriations from public funds when a functioning Board of Supervisors refused to do so.

\section{b. Powers of the Board of Supervisors}

Present charter provisions describing the powers of the Board of Supervisors were also in effect in 1975. The first sentence of section 2.101 states that "[t]he powers of the city and county, except the powers reserved to the people or delegated to other officials, boards, or commissions by this charter, shall be vested in the board of supervisors ...."135 Since the issue is exactly what power had been delegated to the Mayor by the unamended einergency provision, section 2.101's language does not end the inquiry. The section does stand for the proposition, however, that residual powers of the municipal government rest with the Board of Supervisors and expresses a preference that in disputed areas involving power relationships between the Mayor and the Board of Supervisors, the Board should prevail. Moreover, section 2.101 estabhishes that "[t]he exercise of all rights and powers of the city and county when not prescribed in this charter, shall be as provided by ordinance or resolution of the board of supervisors." 136

The charter does prescribe the method for determining salary levels for police and fire personnel. The third sentence of section 2.101, the first specific grant of power to the Board, states that the Supervisors "shall fix rates and schedules of compensation therefor in the manner provided in this charter."137 Section 8.405 specifically

133. Id.

134. Id. $\$ 2.302$, at 4597 .

135. Id. $\$ 2.101$, at 4593. See also C. Elliot, Municipal CoRporations $\S 137$ (3d ed. 1925) (as a general rule, all powers of a city are exercised through the body in which legislative function is vested).

136. Charter of the City and County of Sau Francisco, res. ch. 273, § 2.101, 1971 Cal. Stats. 4593.

137. Id. 
describes the manner for establishing police and fire salaries, and vests power in the Board to pass salary ordinances covering such personnel. ${ }^{138}$ Mayor Alioto's action thus ran directly counter to several explicit cliarter provisions.

\section{c. Emergency Powers Under the Charter}

One of the most widely accepted rules of statutory construction applied in California is that all legislation dealing with the same subject matter should be construed together to achieve harmony of purpose. ${ }^{130}$ Although the harmony-of-purpose rule may be somewhat artificial when applied to isolated snippets of legislation only tangentially related topically and separated by the passage of time, it is particularly applicable to the interpretation of charters, which are organic documents establishing the frameworks of municipal government. In order to understand the scope of mayoral emergency authority under the unamended charter provision, therefore, the emergency powers of the Board of Supervisors must also be examined.

Section 2.300 of the present charter, in effect in 1975, provides that the Board of Supervisors may pass emergency ordinances by a threefourths vote, thereby waiving the normal requirements of committee referral and readings and votes at separate meetings of the Board..$^{140}$ Unless vetoed, these ordinances become effective immediately upon passage instead of 30 days later. ${ }^{141}$ Section 2.300's provisions allow the Board to exercise its prescribed powers swiftly and effectively should circumstances so dictate. That the unamended mayoral emergency powers did not override this provision is suggested by section 9.108 of the cliarter, which provides that "ordinances necessary to enable the mayor to carry out any of the powers vested in him in the case of a public emergency as defined in section 3.100 of the charter . . . shall not be subject to referendum." 142 Yet what ordinance could possibly have been necessary to enable the Mayor to carry out public emergency powers, if the Mayor could liave suspended provisions of the charter vesting legislative power in the Board and could have legislated pursuant to an executive declaration of public emergency? Such an interpretation

138. Id. $\S 8.405$, at 4756 .

139. See, e.g., In re Marquez, 3 Cal. 2d 625, 45 P.2d 342 (1935); Boyd v. Huntington, 215 Cal. 473, 11 P.2d 383 (1932); Hayne v. City \& County of San Francisco, 174 Cal. 185, 162 P. 625 (1917); See also 2 E. McQuillan, Municipal Corporations $\$ 9.22$ (rev. vol. 1966); 2A SUTHERLAND, supra note 89, § 51.02.

140. Charter of the City and County of San Francisco, res. ch. 273, § 2.300, 1971 Cal. Stats. 4595.

141. Id.

142. $I d . \S 9.108$, at 4855-56. 
would render section 9.108 nugatory, an awkward result disfavored by California judicial and statutory authority. ${ }^{143}$

An expansive interpretation of the unamended emergency provision that allows the Mayor to suspend other charter provisions is further embarrassed by section 2.102, which states that the Board of Supervisors in time of disaster shall have the powers conferred by California law pertaining to the preservation of local governinent "notwithstanding anything to the contrary in this charter."144 The charter drafters demonstrably knew how to use language to fashion powers that, when validly exercised, would override other charter provisions. ${ }^{145}$ No such language appears in the unamended emergency provision.

None of the textual points standing alone is conclusive, but cumulatively they make a persuasive case against reading the charter's unamended emergency powers as allowing the Mayor to oust legislative powers froin a functioning Board of Supervisors when a disagreenent existed over how to handle an emergency. Limiting the Mayor's power to this extent would not have made the unamended einergency provision meaningless. The Mayor would still have been empowered to mobilize municipal forces, as did Mayor Schmitz 70 years ago, ${ }^{146}$ to order the demolition of damaged structures without usual condemnation proceedings, ${ }^{147}$ or to direct purchase of air raid sirens in time of war without bids. ${ }^{148}$ But under this interpretation of the unamended emergency clause, the Mayor could not have legislated unless the Board of Supervisors was incapable of acting. ${ }^{149}$

143. San Christina Inv. Co. v. City \& County of San Francisco, $167 \mathrm{Cal} .762$, 772, 141 P. 384, 388 (1914); Cal. Clv. Proc. Code \& 1858 (West 1970). See also 2A SUTHERLAND, supra note $89, \S 46.06$. If the Board of Freeholders actually intended to confer extraordinary legislative powers in the Mayor during times of emergency, it is surprising that Francis Keesling does not comment upon this expansion of power in his commentary on the charter, but does discuss the relatively less significant feature of section 25 authorizing the Mayor to conduct studies in anticipation of emergencies. See note 97 supra.

144. Charter of the City and County of San Francisco, res. ch. 273, $\$ 2.102,1971$ Cal. Stats. 4594.

145. Id.

146. See text accompanying notes 97-102 supra.

147. See Proclamation by Mayor John F. Shelley, Apr. 11, 1966 (ordering demolition of severely damaged buildings following five-alarin fire); Proclamation by Mayor John F. Shelley, Sept. 1, 1966 (ordering demolition of fire-damaged buildings within 3 days); cf. Proclamation by Acting Mayor Peter Tamaras, Jan. 22, 1967 (authorizing temporary evacuation of area where sudden earth slippage presented safety hazard), all on file in the Office of the Mayor, San Francisco, California.

148. Proclamation by Mayor Eliner Robinson, Jan. 2, 1951, on file in the Office of the Mayor, San Francisco, California.

149. This rule has a firm policy footing. It assures that municipal government at all times has some method of meeting a crisis, but sharply circumscribes the emergency legislative power of the Mayor, thereby decreasing the risk of abuse. See Hart, 


\section{The Propriety of Judicial Intervention}

Even assuming Mayor Alioto's action exceeded his authority and that judicial intervention was appropriate, the question remains whether a court could have fashioned a proper remedy. Courts, of course, should not intervene by injunction or other extraordinary remedy when to do so would be inequitable. ${ }^{150}$ In this regard, it could be argued that the Board of Supervisors and the voters assumed the validity of the Mayor's settlement by proposing and approving what could be characterized as punitive charter amendments. ${ }^{151}$ Judicial intervention could unduly distort the results of this political process. If courts are ill-suited to plumb the depths of the legislative mind, however, fathoming the intent of the electorate seems even more beyond judicial competence. How could a court determine whether the electorate, in passing the charter amendinents, was reacting to the Mayor's settlement or to the strike itself? Because it is literally inpossible to answer this question, the courts should have proceeded without regard to the electoral results.

It could also be argued that in returning to work, the police officers and firefighters relied on the settlement's validity, thereby creating a reliance interest worthy of equitable protection by the court. Since the Controller of San Francisco deposited the would-be salary increases under the Mayor's settlement into a special fund pending the outcoine of litigation, ${ }^{152}$ however, the inost potent of reliance interests was not present: that which would have arisen if police officers and firefighters had actually received the Mayor's proclaimed salary increases and applied the funds to household or personal uses. That the paychecks were not actually increased by the settlement seems fair notice that the Mayor's action was subject to potentially invalidating judicial review. Any equitable argument against judicial intervention based on the reliance interests of police officers and firefighters thus seems unpersuasive.

The Emergency Ordinance: A Note on Executive Power, 23 ColuM. L. Rev. 528, 529 (1923). Cf. 1 E. MCQuillin, Municipal Corporations $\$ 10.42$ (rev. vol. 1965) (noting that a city council cannot normally delegate legislative powers to other officials, but it can authorize others to act when the council cannot do so "understandingly" or"advantageously").

150. For taxpayer suits where injunctions have not been issued despite technical illegality, see Griffith v. City of Los Angeles, $78 \mathrm{Cal}$. App. 2d 796, 178 P.2d 793 (2d Dist. 1947); Ege v. Williams, 38 S.D. 50, I59 N.W. 898 (1916).

151. The Board of Supervisors, however, though named as a defendant in Verreos, joined the taxpayer plaintiff in urging the court to invalidate the Mayor's settlement. See text following note 4 supra.

152. Two Case Studies, supra note 7, at 22. 


\section{CONCLUSION}

In reviewing declarations of emergency by municipal executives, California courts should generally defer to executive judgment. Barring fraud, insufficient suddenness, or "nursing," executive declarations of emergency pursuant to explicit charter provision should not be overturned by a court unless fraudulent, arbitrary, and capricious. Using this standard, Mayor Alioto's declaration of emergency durnig the police and fire strike of 1975 was valid.

Assuming the existence of a public emergency, the question remains whether Mayor Alioto acted within the scope of authority vested in the Mayor by the executive emergency provisions of the San Francisco Charter. The history of municipal government in San Francisco, along with textual analysis of the allocation of power under the charter indicates that Mayor Alioto did not have the power, even during an ennergency, to "suspend" legislative provisions of the charter and grant wage imcreases to striking public safety officers when the Board of Supervisors was functioning nornially. Because Mayor Alioto overreached his power under the charter, his settlement of the strike should have been invalidated in Verreos. Since there were no persuasive equitable arguments against judicial intervention, the court should have enjoined the City and County of San Francisco froin disbursing the salary increases that the Mayor attempted to impose.

Brent Appel*

* B.A., M.A. 1973, Stanford University; third-year student, Boalt Hall School of Law; Research Editor, California Law Review. 